\title{
Alabama: Maturing Party Competition
}

\author{
Patrick R. Cotter, Samuel H. Fisher III, and Patrick Fuller
}

After years of a virtual Democratic monopoly over its electoral politics, Alabama has become a politically competitive state. Reflecting this political transformation, the results of the 1991 and 2001 Grassroots Party Activists surveys show that Alabama's Democratic and Republican party activists are increasingly distinguishable in their social characteristics, ideological stands, and policy positions. Also accompanying the state's new political competitiveness has been the development of party organizations that are now roughly balanced in terms of their strength and capabilities.

\section{Introduction}

Alabama has become familiar with party competition. The days of Democratic dominance over Republicans in state politics are long past. Now, Alabama's statewide elections are frequently close contests, the mixed results of which typically give both parties reasons for both regret and rejoicing. ${ }^{1}$ The results of the Alabama segment of the Grassroots Party Activists survey show that this competitiveness has been accompanied by the development of party organizations which have grown more balanced in terms of their strengths and capability, but have also become increasingly distinct in their policy views.

\section{Development of Political Parties in Alabama}

The current competitiveness of Alabama's politics is least apparent in presidential elections. Republicans have carried the state in the six elections since 1980. Several of these elections have been close contests, however, attracting the campaign attention of one or both major parties and candidates (Table 1). After winning the state by a large margin in 1976, Democrat Jimmy Carter was defeated by Ronald Reagan in 1980 by less than 20,000 votes. More recent Democratic southerners have fared less well. Bill Clinton lost by more than 100,000 votes in 1992 and 1996, while Al Gore's defeat in 2000 was akin to the beatings received by Walter Mondale and Michael Dukakis in the 1980s (Cotter 2002; Stanley 2003).

Republicans also dominate the state's congressional delegation. Since 1992, the GOP has controlled five of the state's seven House seats (though,

PATRICK COTTER is a professor at the University of Alabama, SAMUEL FISHER is an associate professor at the University of South Alabama, and PATRICK FULLER is a graduate student in the Department of Political Science at the University of Alabama.

The American Review of Politics, Vol. 24, Spring, 2003: 21-34

(C)2003 The American Review of Politics 
Table 1. Republican Strength in Alabama, 1960-2000

\begin{tabular}{|c|c|c|c|c|c|c|}
\hline Year & $\begin{array}{l}\text { Percent of } \\
\text { Presidential } \\
\text { Vote }\end{array}$ & $\begin{array}{l}\text { Percent of } \\
\text { Gubernatorial } \\
\text { Vote }\end{array}$ & $\begin{array}{l}\text { Percent of } \\
\text { U.S. Senate } \\
\text { Vote }\end{array}$ & $\begin{array}{l}\text { Percent of } \\
\text { U.S. House } \\
\text { Delegation }\end{array}$ & $\begin{array}{l}\text { Percent of } \\
\text { State House } \\
\text { Delegation }\end{array}$ & $\begin{array}{l}\text { Percent of } \\
\text { State Senate } \\
\text { Delegation }\end{array}$ \\
\hline 1960 & 42.1 & & 29.8 & 0.0 & 0.0 & 0.0 \\
\hline 1962 & & 0.0 & 49.1 & 0.0 & 1.9 & 0.0 \\
\hline 1964 & 69.5 & & & 62.5 & 1.9 & 0.0 \\
\hline 1966 & & 31.0 & 39.0 & 37.5 & 0.0 & 2.9 \\
\hline 1968 & 14.0 & & 22.1 & 37.5 & 0.0 & 2.9 \\
\hline 1970 & & 0.0 & & 37.5 & 1.8 & 0.0 \\
\hline 1972 & 72.4 & & 33.1 & 42.8 & 1.9 & 0.0 \\
\hline 1974 & & 14.8 & 0.0 & 42.8 & 0.0 & 0.0 \\
\hline 1976 & 42.6 & & & 42.8 & 1.9 & 0.0 \\
\hline 1978 & & 25.9 & 43.0 & 42.8 & 4.0 & 0.0 \\
\hline 1980 & 48.8 & & 50.0 & 42.8 & 4.0 & 0.0 \\
\hline 1982 & & 39.1 & & 28.6 & 7.6 & 8.6 \\
\hline 1984 & 60.5 & & 36.4 & 28.6 & 12.1 & 12.5 \\
\hline 1986 & & 56.3 & 49.7 & 28.6 & 15.2 & 14.3 \\
\hline 1988 & 59.2 & & & 28.6 & 16.2 & 17.1 \\
\hline 1990 & & 53.3 & 39.4 & 28.6 & 21.0 & 20.0 \\
\hline 1992 & 47.6 & & 33.1 & 42.9 & 21.9 & 20.0 \\
\hline 1994 & & 50.3 & & 71.4 & 29.5 & 34.3 \\
\hline 1996 & 50.1 & & 52.5 & 71.4 & 31.4 & 35.3 \\
\hline 1998 & & 42.1 & 63.2 & 71.4 & 32.4 & 37.4 \\
\hline 2000 & 56.5 & & & 71.4 & 34.3 & 35.2 \\
\hline 2002 & & 49.2 & 58.6 & 71.4 & 40.0 & 29.9 \\
\hline \multicolumn{7}{|c|}{$\begin{array}{l}\text { Note: Entries are the Republican percentage of the vote (for the first three columns) or the Repub- } \\
\text { lican percentage of seats won in the election (for the last three columns). In } 1978 \text {, there also was a } \\
\text { special election with no Republican candidate; the results of this election ( } 0 \% \text { for the Republican) } \\
\text { are not shown in the table. }\end{array}$} \\
\hline
\end{tabular}

with the post-2000 redistricting, an under-funded Democrat came close to winning one of these seats in 2002). Both of Alabama's U.S. Senators are Republicans. One, Richard Shelby, was initially elected as a Democrat in 1986. He switched parties the day after the 1994 election-a contest in which Republicans gained a majority of seats in Congress. The other Senator, Jeff Sessions, was elected to an open seat in 1996 and then reelected in 2002 against a relatively unknown Democratic opponent.

The results of Alabama's recent gubernatorial elections provide a good illustration of the state's growing party competition. Republican Fob James won the governorship in 1994 after having held the office as a Democrat from 1979 to 1983. He defeated incumbent governor Jim Folsom, Jr., the son of two-term governor "Big Jim" Folsom by less than one percent of the 
vote. James's narrow victory was aided by the Republican trend nationally, as well as by allegations of ethical misconduct in the Folsom administration. Ironically, Folsom was elevated to the governorship in 1993 after Republican Guy Hunt was removed from office following his conviction of the state's ethics law (Cotter and Gordon 1999).

James's electoral vulnerability was evident in 1998. Despite being the incumbent, James was challenged by several serious candidates in the GOP primary. A vocal advocate of issues like school prayer, James had strong support among social conservatives. James's most serious challenge came from Winton Blount, a Montgomery businessman and the son of "Red" Blount, one of the pioneering members of the state's post-World War II Republican Party (Strong 1972). A third candidate for the nomination was former governor Hunt. Shortly before the filing deadline for the primary, the state's Pardons and Parole Board had granted Hunt a pardon on the grounds of "innocence." Hunt promptly entered the gubernatorial race. He finished third, but gained enough votes to force a runoff between James and Blount. Hunt endorsed Blount in the runoff, but James prevailed to capture the Republican nomination.

The weaknesses exposed in the primary fight proved costly to James in the 1998 general election. He was soundly defeated by Democrat Don Siegelman. Siegelman's election was a major victory for Alabama's Democrats, since he was the first Democrat elected to the governorship since George Wallace in 1982. The centerpiece of Siegelman's campaign was his support for a state lottery. A lottery, Siegelman argued, would provide the revenue necessary to address problems in the state's public education system (Stanley 2003, 89-90).

When put to a vote, Siegelman's lottery proposal was defeated in a special referendum by 54 to 46 percent. Undaunted, Siegelman used the issue again in his reelection bid in 2002. He lost to Republican Bob Riley by a few thousand votes, making him the third consecutive governor to lose a reelection bid. Riley's campaign focused on the need to reform and improve Alabama's state government, particularly in light of financial scandals associated with the Siegelman administration.

Democratic dominance of the executive branch of the state government has declined in recent years in the face of Republican gains. In 2002, Democrats won only four of the nine statewide positions up for election (Lieutenant Governor, Secretary of State, Public Service Commissioner and Commissioner of Agriculture and Industry). However, Democrats remain formidable at the state legislative level. While the number of Republicans has grown, Democrats continue to hold a large majority both houses of the state legislature. After the 2002 election, Democrats held 60 percent of the House seats and 71 percent of the Senate seats. 
Another sign of the competitiveness of the state's politics is seen in the party identifications of rank-and-file Alabamians. The Democratic advantage in partisan identifiers reached nearly 40 percentage points in 1982 before dropping off dramatically in 1984 . There is now a rough parity in number of Democratic and Republican identifiers in the state. Further, neither party can claim the allegiance of a majority of Alabamians (Cotter and Stovall 1996).

As in other southern states, party organizations in Alabama were slow to develop. Republicans made initial inroads at the state level in the early 1960 s, setting the stage for victories by presidential nominee Barry Goldwater and several lower-ticket Republicans in the 1964 elections. Republican successes spurred Democratic organizational development. In both parties, ideological disputes and interpersonal conflicts have reduced the overall effectiveness of the state party organizations (Cotter 1997).

\section{Grassroots Party Activists, 2001 and 1991}

Alabama's Democratic and Republican party activists reflect the state's established competitive politics. Specifically, the results of the Grassroots Party Activists survey show that, in a number of important ways, the two parties have become politically more distinct. At the same time, the results also show that, in terms of organizational characteristics, the two parties have moved towards a greater degree of similarity. Neither party's organization is particularly close knit, integrated, or involved. The two parties have, however, become more equal in terms of the resources, loyalty, and activity levels of their members.

\section{Social Characteristics}

The 1991 Alabama study found important political differences (and fewer similarities) between Democratic and Republican political activists. During the last decade, some of these differences, particularly those involving characteristics related to the organizational capabilities of the parties, have diminished in size. Other partisan differences remained relatively stable, while differences regarding still other characteristics have increased in size.

Areas of diminishing partisan differences. Socio-economic characteristics is one area in which partisan differences among activists have diminished. The 1991 study found that Republicans were generally more educated and had a higher family income than did their Democratic counterparts. Now, however, Democratic and Republican activists are more similar to one another in terms of education and family income (Table 2). More than half of both parties' activists now hold college degrees. Incomes in both parties 
Table 2. Demographic Profiles of Alabama Party Activists, 1991 and 2001

\begin{tabular}{|c|c|c|c|c|}
\hline & \multicolumn{2}{|c|}{2001} & \multicolumn{2}{|c|}{1991} \\
\hline & Democrats & Republicans & Democrats & Republicans \\
\hline \multicolumn{5}{|l|}{ Education } \\
\hline High school or less & 19 & 14 & 31 & 14 \\
\hline Some college & 26 & 33 & 26 & 32 \\
\hline College graduate & 15 & 22 & 13 & 27 \\
\hline Graduate degree & 40 & 31 & 30 & 27 \\
\hline \multicolumn{5}{|l|}{ Family Income } \\
\hline Less than $\$ 50,000(\$ 30,000)$ & 35 & 30 & 36 & 16 \\
\hline$\$ 50-74,999(\$ 30-49,999)$ & 27 & 26 & 25 & 32 \\
\hline$\$ 75-99,999(\$ 50-69,999)$ & 18 & 20 & 19 & 26 \\
\hline More than $\$ 100,000(\$ 70,000)$ & 21 & 25 & 20 & 27 \\
\hline \multicolumn{5}{|l|}{ Race } \\
\hline White & 77 & 98 & 86 & 97 \\
\hline African-American & 21 & 1 & 11 & 1 \\
\hline Other & 2 & 1 & 3 & 1 \\
\hline \multicolumn{5}{|l|}{ Gender } \\
\hline Male & 57 & 75 & 74 & 71 \\
\hline Female & 43 & 25 & 26 & 29 \\
\hline \multicolumn{5}{|l|}{ Attend religious service } \\
\hline Once a week or more & 60 & 69 & 52 & 52 \\
\hline Almost every week & 10 & 12 & 20 & 16 \\
\hline Once or twice a month & 12 & 6 & 10 & 11 \\
\hline Few times a year/never & 19 & 13 & 18 & 21 \\
\hline \multicolumn{5}{|l|}{ Age } \\
\hline Median years & 58 & 59 & 59 & 53 \\
\hline \multicolumn{5}{|l|}{ Grew Up } \\
\hline Alabama & 89 & 75 & 89 & 71 \\
\hline Other Southern State & 6 & 15 & 7 & 12 \\
\hline Outside South & 9 & 11 & 4 & 17 \\
\hline \multicolumn{5}{|c|}{$\begin{array}{l}\text { Note: Entries are percentages, by column, except for age, where the median is reported. For income, } \\
\text { the numbers in parentheses are the category breaks for } 1991 \text {. For example, the highest income cate- } \\
\text { gory in } 2001 \text { was "more than } \$ 100,000 " \text {; in } 1991 \text {, it was "more than } \$ 70,000 . "\end{array}$} \\
\hline
\end{tabular}


rose across the decade, especially among Democrats. One in four Republicans and one in five Democrats reported family incomes of more than $\$ 100,000$ in 2001.

The parties have also become similar with regard to the age of activists. In 1991, Democratic activists were generally older than their GOP counterparts. Since then, the median age of Democratic activists has remained relatively stable at slightly less than 60 years old. However, the median age of Republican activists has increased. As a result, there is now little age difference between Democratic and Republican activists.

Areas of stable partisan differences. There are also several areas in which partisan differences or similarities have remained relatively stable. Specifically, native southerners continue to constitute a large majority of both parties' activists. Democratic activists are, however, still more likely than their GOP counterparts to be native Alabamians. Also, some political background characteristics have remained similar for the two groups (see Table 3). For example, when it comes to the partisan involvement of their families, about half of both Democratic and Republican activists say that they come from families whose members were politically active. Additionally, more than 80 percent of Democratic activists say that their parents were also Democrats in both 1991 and 2001. Pluralities of Republicans also continue to say that their parents were Democrats. The finding that less than one-half of GOP activists say that their mothers or fathers identified

Table 3. Political Background of Alabama Party Activists, 1991 and 2001

\begin{tabular}{lrrrr}
\hline & \multicolumn{2}{c}{2001} & \multicolumn{2}{c}{1991} \\
& Democrats & Republicans & Democrats & Republicans \\
\hline Mother's party & & & & \\
$\quad$ Democrat & 87 & 48 & 88 & 46 \\
$\quad$ Independent & 6 & 16 & 8 & 21 \\
$\quad$ Republican & 7 & 36 & 4 & 34 \\
Father's party & & & & \\
$\quad$ Democrat & 57 & 46 & 88 & 47 \\
$\quad$ Independent & 5 & 13 & 6 & 18 \\
$\quad$ Republican & 5 & 15 & 6 & 23 \\
Ever belong to other party & 5 & & 2 & 45 \\
Had parents/relatives & & 47 & 49 & \\
active in parties & 51 & & & \\
Note: Entries are percentages, by column. & & & & \\
\hline
\end{tabular}


themselves as Republicans is, of course, consistent with both the traditional Democratic dominance in Alabama and the more recent increase in Republican strength within the state (Cotter and Stovall 1996). This political shift is also reflected in the results showing that Republican activists are more likely than Democratic activists to say that they once belonged to the opposing political party.

Areas of increasing partisan differences. One area in which partisan differences has grown is the racial composition of Democratic and Republican activists. Both the 1991 and 2001 studies found that almost all Republican activists are white (see Table 2). Whites, however, make up a smaller proportion of Democratic activists in 2001, as the proportion of AfricanAmericans among Democratic activists increased from about 11 percent in 1991 to 21 percent in 2001. Similar changes in the difference between the parties are found regarding gender. Between 1991 and 2001 the proportion of females among Republicans remained stable. However, among Democratic activists, the proportion of women rose sharply from 26 to 43 percent.

Grassroots activists in Alabama are highly religious, even more so than a decade ago. Then, 52 percent of the activists in each party reported attending religious services at least once a week. In the 2001 survey, Republicans are somewhat more likely than Democrats to say that they attend religious services one or more times a week. Two-thirds of the activists in both parties identified themselves as "Born-Again" Christians. Similar proportions indicated that religion had a "great deal" of influence on their daily lives.

\section{Ideology and Policy Views}

Ideology and policy views highlight another area in which partisan differences have increased among Alabama's party activists. During the last decade, Alabama's Democratic activists became more liberal, while their GOP counterparts became more strongly conservative (Table 4). Specifically, in 1991, when Democrats were asked to describe themselves ideologically, the survey found a roughly equal division between liberals, conservatives and moderates. The 2001 study found, however, that a majority of Democrats now label themselves as either "very liberal" or "somewhat liberal." Less than one-fifth of the Democrats identify themselves as "somewhat conservative" or "very conservative."

Among Republicans, the heightened level of conservatism is not the consequence of a decreasing number of moderates or liberals within the party. In both 1991 and 2001 few Republican activists identified themselves in these terms. Rather, the change is due to an increase in the number of "strong conservatives" among GOP activists. In 1991 about 38 percent of Republican activists said that they were "strong conservatives." A decade later, a majority described themselves this way. 
Table 4. Ideological Orientation of Alabama Activists, 1991 and 2001

\begin{tabular}{lcccc}
\hline & \multicolumn{2}{c}{2001} & \multicolumn{2}{c}{1991} \\
& Democrats & Republicans & Democrats & Republicans \\
\hline Very liberal & 16 & 0 & 10 & 1 \\
Somewhat liberal & 37 & 2 & 20 & 2 \\
Middle road/moderate & 27 & 6 & 32 & 11 \\
Somewhat conservative & 13 & 38 & 30 & 49 \\
Very conservative & 6 & 54 & $\frac{8}{100 \%}$ & $\frac{38}{100 \%}$ \\
& $100 \%$ & $100 \%$ & $(429)$ & $(584)$ \\
(N) & $(380)$ & $(430)$ & 3.1 & 4.2 \\
Mean & 2.6 & 4.4 & & \\
Note: Entries are percentages, by column. Ns are in parenthesis. Mean scores are calculated using a \\
five point scale (very liberal=1; very conservative=5). \\
\hline
\end{tabular}

A similar pattern of increased polarization is found when examining the issue positions of activists. Table 5 displays the mean issue positions for each parties' activists. ${ }^{2}$ Both the 1991 and 2001 surveys show that Alabama's Democratic and Republican party activists generally take different positions on issues. Further, on each of the issues examined, Democrats are typically more "liberal" in their views than are Republicans. Differences are particularly large with regard to the provision of government services, gun control, school vouchers, government regulation of health care, and abortion. Smaller party differences are found regarding equal rights for women, prayer in public schools, the use of racially based preferences in employment decisions, and the death penalty. Activists in both parties adopted conservative positions on the role of the government in guaranteeing a good standard of living, the death penalty, racially-based preferences in hiring decisions, and school prayer. Both parties' activists adopted a liberal stand on only one issue, whether women should have an equal role in politics and business.

Additionally, the results presented in Table 5 show that the opinion gap between the parties has generally widened between 1991 and 2001. For example, in 1991, Republican activists were about 40 percent more "conservative" in their opinions about spending on government services than were Democratic activists. In 2001, the partisan difference had increased to 58 percent. The issue of equal rights for women is the only exception to this pattern of increasing partisan polarization as both parties shifted in a liberal direction. 
Table 5. Issue Orientation of Alabama Activists, 1991 and 2001

\begin{tabular}{|c|c|c|c|c|}
\hline & \multicolumn{2}{|c|}{2001} & \multicolumn{2}{|c|}{1991} \\
\hline & Democrats & Republicans & Democrats & Republicans \\
\hline Govt services/spending & 1.8 & 2.9 & 2.2 & 2.9 \\
\hline Control handguns & 1.9 & 3.2 & \multicolumn{2}{|c|}{ not asked } \\
\hline School vouchers & 1.6 & 2.8 & \multicolumn{2}{|c|}{ not asked } \\
\hline Regulation managed care & 2.1 & 3.1 & \multicolumn{2}{|c|}{ not asked } \\
\hline Abortion & 1.9 & 3.1 & 2.2 & 2.8 \\
\hline Economic position women & 1.8 & 2.7 & 1.9 & 2.5 \\
\hline Job discrimination - gays & 2.3 & 3.2 & \multicolumn{2}{|c|}{ not asked } \\
\hline Position Blacks/minorities & 2.0 & 2.7 & 2.4 & 2.9 \\
\hline Jobs/standard living & 2.6 & 3.4 & 2.5 & 3.2 \\
\hline Flat tax & 2.4 & 3.2 & \multicolumn{2}{|c|}{ not asked } \\
\hline Death penalty & 2.6 & 3.2 & \multicolumn{2}{|c|}{ not asked } \\
\hline Blacks hiring/employment & 2.9 & 3.6 & 3.1 & 3.6 \\
\hline School prayer & 3.1 & 3.5 & 3.3 & 3.5 \\
\hline Women equal role & 1.5 & 1.7 & 1.9 & 2.1 \\
\hline (Average $\mathrm{N}$ agree/disagree) & (386) & (437) & $(418)$ & (574) \\
\hline
\end{tabular}

\section{Organizational Strength}

The 1991 study showed that Alabama's Republican party had a clear organizational advantage over its Democratic opponent. Political skills, party loyalty, and involvement were higher among GOP activists. Republicans were also more likely than their Democrat counterparts to see an increase in their party's organizational strength and effectiveness.

Several results from the 2001 study indicate that this organizational gap has narrowed, though not disappeared. First, successful political parties require skillful and involved members. The 1991 study found that the parties were not equal in the resources of their activists. Then, as discussed earlier, Republicans were generally more educated and had a higher family income than did their Democratic counterparts. Now, however, the state's two parties are roughly balanced with regard to the potential skills and abilities of their activists. Indeed, both parties at the grassroots are currently composed largely of individuals who possess the educational and financial resources needed for political involvement. Similarly, as also discussed previously, the age of activists (which may indicate either "experience" and/or energy level) is another area in which the parties have become similar. 
Second, in 1991, Republican activists were more loyal to their party, particularly the national party, than were Democrats. Now, the loyalty of Democratic activists to the national party has increased to a point roughly equal to that found among Republicans. For example, among Republicans, about 99 percent of the activists say that they voted for either the elder or junior George Bush in the 1988 or 2000 election, respectively. Democratic activists (91 percent) were somewhat less likely to support Al Gore in 2000 election. Still, this is higher than the 75 percent of Democratic activists who voted for Massachusetts governor Michael Dukakis in 1988.

Similarly, in 2001, Democrats were less likely than Republicans to say that they "strongly" identified with their national party. This difference, however, was larger in 1991, when 70 percent of Democrats and 89 percent of Republicans were strong national party identifiers. In both 1991 and 2001, strength of identification is about the same for each group with regard to the state party. For example, in 2001, 89 percent of Democrats and 91 percent of Republicans strongly identify with their state party.

Third, as representatives of their parties at the most local level, both Democratic and Republican grassroots activists are more concerned with local elections than they are with national or state contests. More than twothirds reported being "very active" in local elections, while half reported such activity in state elections. Thirty-nine percent of Democrats and 48 percent of Republicans were very active in national elections. Among Democrats, the level of involvement in different types of campaigns remained roughly the same between 1991 and 2001. In contrast, the level of campaign involvement among Republican activists has declined. For example, the number of Democrats saying that they were "very active" in state elections did not change between 1991 and 2001. Among Republicans, however, the number saying that they are very active in state elections decreased from 63 percent in 1991 to 51 percent in 2001. Smaller declines for GOP activists were found regarding activity in local and national elections.

Fourth, the diminishing organizational difference between the parties is also indicated by questions asking respondents to identify what activities they carried out in recent election campaigns. Table 6 shows that in 1991, Republicans were generally more active than were Democrats. In 2001, however, partisan differences in activity levels have largely either decreased or, for some campaign practices, been reversed. For example, in 1991, Republicans were about 18 percent more likely than Democrats to say that they had distributed posters or lawn signs. Now, GOP party activists continue to out-perform their Democratic counterparts in this area, but by a smaller 8 percent margin. For some mobilization activities, Democrats improved their performance levels while Republicans became less likely to engage in the activity. Examples include organizing campaign events, door- 
Table 6. Campaign Activities of Alabama Activists, 1991 and 2001

\begin{tabular}{lcccc}
\hline & \multicolumn{2}{c}{2001} & \multicolumn{2}{c}{1991} \\
Type of Activity & Democrats & Republicans & Democrats & Republicans \\
\hline Distributed posters/lawn signs & 74 & 82 & 52 & 70 \\
Distributed campaign literature & 73 & 78 & 65 & 77 \\
Contributed money & 62 & 79 & 58 & 80 \\
Organized campaign events & 44 & 38 & 32 & 44 \\
Organized door-to-door & & & & 32 \\
$\quad$ canvassing & 38 & 25 & 28 & 50 \\
Sent mailings to voters & 39 & 44 & 30 & 19 \\
Conducted voter registration & 28 & 20 & 19 & 38 \\
Arranged fundraising & 28 & 40 & 24 & 40 \\
Organized telephone campaigns & 27 & 27 & 24 & 34 \\
Dealt with campaign media & 25 & 31 & 22 & 9 \\
Used public opinion surveys & 11 & 9 & 10 & \\
Purchased billboard space & 7 & 6 & & not asked \\
Helped construct or maintain & & & & \\
$\quad$ website & 4 & 4 & & \\
Note: Entries are the percent who said that they engaged in the activity in recent campaigns. \\
\hline
\end{tabular}

to-door canvassing, sending mailings, and (to a lesser extent) organizing telephone campaigns.

Fifth, activists' assessments of their party's resources and effectiveness also indicate that the difference between Alabama's Democratic and Republican parties is (slowly) growing smaller. Specifically, both the 1991 and 2001 surveys contained a set of items on which respondents were asked if their party had gotten stronger or weaker in recent years with regard to a number of organizational characteristics. These results can be summarized by subtracting the proportion of respondents who say that their party has grown "weaker" in an area of party activity from the proportion who say their party had grown "stronger." If the result is a number greater than zero, then party members generally believe that their party has increased in strength. Numbers less than zero indicate that activists generally feel their party has grown weaker.

Table 7 shows that in both 1991 and 2001, Republicans are substantially more likely to say that their party has gotten stronger, rather than weaker, with regard to both "overall" organization and more specific activities such as campaign effectiveness, fund raising and candidate recruitment. Democrats, in contrast, are more divided concerning whether their party has gotten stronger or weaker. The difference between parties is particularly 
Table 7. Changes in Perceived Strength of Party Organizations, Alabama Party Activists, 1991 and 2001

\begin{tabular}{|c|c|c|c|c|}
\hline \multirow[b]{2}{*}{ Change in Party Strength } & \multicolumn{2}{|c|}{2001} & \multicolumn{2}{|c|}{1991} \\
\hline & Democrats & Republicans & Democrats & Republicans \\
\hline Overall county party organization & +5 & +77 & -3 & +79 \\
\hline Campaign effectiveness & +6 & +75 & -1 & +69 \\
\hline Ability to raise funds & +10 & +74 & +3 & +65 \\
\hline Organizational skills of workers & +10 & +52 & +4 & +54 \\
\hline Recruiting candidates & +11 & +66 & +9 & +66 \\
\hline Use of opinion polls & +20 & +28 & +10 & +46 \\
\hline Use of media & +22 & +57 & +19 & +54 \\
\hline Use of computers & +48 & +63 & +27 & +56 \\
\hline Strength among county voters & -1 & +81 & \multicolumn{2}{|c|}{ not asked } \\
\hline$($ Average $\mathrm{N})$ & $(382)$ & $(435)$ & $(404)$ & $(573)$ \\
\hline
\end{tabular}

large with regard to activists' assessments of their parties' overall organization, campaign effectiveness and fund raising. Partisan differences are somewhat smaller regarding "newer" aspects of politics, such as the use of opinion polls and computers (both state parties maintain websites containing information about party activities).

Republicans' assessments of their party's strengths and weaknesses remained relatively unchanged between 1991 and 2001 (with the exception of "use of opinion polls"). Democrats' evaluations of their party also experienced little change. However, what change did occur among Democrats was uniformly in the positive direction, indicating a stronger party. Thus, while the Democratic party may continue to lag behind the GOP in terms of organizational resources and effectiveness, perhaps the gap is getting smaller.

Finally, one measure from the 2001 study may run counter to the conclusion of a narrowing organizational gap between Alabama's Democratic and Republican parties. This indicator involves the level of disagreement, or factionalism, found within each party. Specifically, the 2001 (but not the 1991) survey included two items asking respondents about the level of factionalism within their state and county party organizations. These items show that Democrats generally see more intra-party divisions than do Republicans. For example, a majority of Democratic activists responding say that there is a "very high" or "moderately high" level of factionalism within their state party. Fewer Republican activists say that the level of party factionalism at the state level is moderately or very high. Among both groups of 
activists, less factionalism is seen at the county than at the state level. Even at the county level, however, more Democrats report a moderate or high level of factionalism than do Republicans.

A similar conclusion is reached by calculating the standard deviations (among each set of party activists) for those issue items that were included in both the 1991 and 2001 surveys. These figures show (results not presented) that overall, while there is variation across specific issues, there is more disagreement among Democrats than among Republicans. Further, within each party, and especially among GOP activists, the average standard deviation for the issue items has gotten smaller. Thus Democrats are more likely to argue with one another than are Republicans. However each party is moving towards more internal consistency.

\section{Conclusion}

Alabama, like its regional neighbors, has experienced much political change in recent decades. The outcome of the Grassroots Party Activists surveys suggests that this period of rapid change may have ended. Democrats and Republicans are increasingly distinguishable in their social characteristics, ideological stands, and policy positions. Further, the organizational attributes of the two parties are becoming more equal.

With these two distinctive and developed parties, Alabama's electoral politics appears to have matured, moving from a period of unpredictability into an era of stable, but closely balanced, politics. Maturity and stability (as some of us know) does not necessarily mean uninteresting or unimportant. Rather, with its developed electoral system, Alabama's politics are likely to remain interesting, hard-fought and highly competitive.

\section{NOTES}

${ }^{1}$ For information about recent Alabama politics see Cotter and Gordon 1999; Ellington 1999; and Stanley 2003. For information about Alabama's politics in the postWorld War II period see Barnard 1974; Grafton and Permaloff 1985; McWhorter 2001; Permaloff and Grafton 1995; Rogers, Ward, Atkins and Flynt 1995; and Sims 1985.

${ }^{2}$ Individual issue positions range from 1 to 4, with higher scores representing more conservative positions. Mean scores below 2.5 indicate that the party's activists adopted a liberal position on average; mean scores above 2.5 indicate an overall conservative position. 
34 | Patrick R. Cotter, Samuel H. Fisher III, and Patrick Fuller

\section{REFERENCES}

Barnard, William. 1974. Dixiecrats and Democrats: Alabama Politics, 1942-1950. University: University of Alabama Press.

Cotter, Patrick R. 2003. Alabama: A 'Small Time' Election. In The 2000 Presidential Election in the South, eds. Robert P. Steed and Laurence W. Moreland. Westport, CT: Praeger.

Cotter, Patrick R. 1997. Alabama. In State Party Profiles, eds. Andrew M. Appleton and Daniel S. Ward. Washington, DC: CQ Press.

Cotter, Patrick R., and Tom Gordon. 1999. Alabama: The GOP Rises in the Heart of Dixie. In Southern Politics in the 1990s, ed. Alexander P. Lamis. Baton Rouge: Louisiana State University Press.

Cotter, Patrick R., and James G. Stovall. 1996. Party Identification and Political Change in Alabama: A Mid-1990s Update. American Review of Politics 17:193-211.

Cotter, Patrick R., James G. Stovall, and Samuel H. Fisher, III. 1994. Disconnected: Public Opinion and Politics in Alabama. Northport, AL: Vision Press.

Ellington, Thomas C. 1999. The Hidden Realignment: The 1986 Gubernatorial Race and Party Loyalty in Alabama. American Review of Politics 20:25-47.

Grafton, Carl, and Anne Permaloff. 1985. Big Mules and Branchheads: James Folsom and Political Power in Alabama. Athens: University of Georgia Press.

McWhorter, Diane. 2001. Carry Me Home: Birmingham, Alabama: The Climatic Battle of the Civil Rights Revolution. New York: Simon \& Schuster.

Permaloff, Anne, and Carl Grafton. 1995. Political Power in Alabama: The More Things Change ... Athens: University of Georgia Press.

Rogers, William Warren, Robert David Ward, Leah Rawls Atkins, and Wayne Flynt. 1994. Alabama: The History of a Deep South State. Tuscaloosa: University of Alabama Press.

Sims, George E. 1985. The Little Man's Big Friend. Tuscaloosa: University of Alabama Press.

Stanley, Harold W. 2003. Alabama: Republicans Winning the Heart of Dixie. In The New Politics of the Old South, eds. Charles S. Bullock, III, and Mark J. Rozell. Lanham, MD: Rowman and Littlefield.

Strong, Donald. 1972. Alabama: Transition and Alienation. In The Changing Politics of the South, ed. William C. Havard. Baton Rouge: Louisiana State University Press. 